\title{
Corporate Social Responsibility Disclosure and Financial Performance of Firms in Kenya: A Stakeholder Approach
}

\author{
Robert A. King'wara \\ Dept. of Accounting, Finance and Management Science, Egerton University \\ PO Box 13357 - 20100, Nakuru, Kenya \\ Tel: 254-723-086-804Ｅ-mail: robert.kingwara@egerton.ac.ke
}

Received: June 17, 2020 Accepted: July 16, 2020 Published: July 21, 2020

doi:10.5296/ber.v10i3.17382ＵRL: https://doi.org/10.5296/ber.v10i3.17382

\begin{abstract}
Using panel data set from companies listed on the Nairobi Securities Exchange in Kenya, a developing country, this paper examines the potential influence of corporate social responsibility disclosure (CSRD) on corporate financial performance. Using data from annual reports, CSRD information was collected for the period 2007-2015 using quantitative content analysis while financial performance data was collected for the period 2008-2016, a one-year lag behind CSRD data. Control variables were firm size, industry type and leverage. There was found to be no statistically significant impact of CSRD on financial performance. Since neutrality of the relationship is empirically proven, the conclusion is that CSRD has little or no contribution to financial performance and the implication is that effective financial reporting for companies listed on the NSE does not include reporting on CSR activities. Theoretically the study proposes that unequal controlling strengths of different stakeholders be assumed under the stakeholder theory for application within different national contexts in order for managers to be able to make the necessary tradeoffs among competing stakeholders.
\end{abstract}

Keywords: Corporate social responsibility, Disclosure, Financial performance, Developing country, Kenya, Panel data

\section{Introduction}

\subsection{Research Problem}

Under instrumental stakeholder theory corporate social responsibility disclosure (CSRD) is an intangible asset in a firm which positively influences key stakeholders and results in positive cash flows which in the long term increase firm value (Tilt, 2018; Roberts, 1992). 
Empirical evidence of the stakeholder theory however is inconclusive. Friedman (1970) argued that business managers have a responsibility to shareholders to maximize firm value and therefore implied that there exists a negative relationship between CSRD and financial performance (Gregory et al., 2014, Mishra \& Modi, 2013, Salama et al., 2011). Other researchers have arrived at a positive CSRD - CFP relationship (Ruf et al. 2001; Simpson \& Kohers, 2002; Tsoutsoura 2004; Waddock \& Graves, 1997) and concluded that there are long-term strategic advantages to be gained by way of differentiation and cost savings that contribute to financial benefits. Findings from other research studies have arrived at a neutral relationship between CSR disclosure and FP (McWilliams \& Siegel, 2000; Griffin \& Mahon, 1997) with the conclusion being that that there exists so many intervening observable and unobservable variables at play between CSR disclosure and FP that a predictable relationship does not exist. These conflicting results lead to a dilemma on the actual effect of CSR disclosure on financial performance. They signify inadequacy of studies conducted into the CSRD-FP relationship. Until a general relationship is established more research need to be conducted to resolve the observed contradictions.

Using archival research, this study seeks to understand the influence of CSRD on financial performance of firms in Kenya. Previous findings have mainly been from research studies that were carried out in developed and high-income countries such as the United States and Australia contrasted to sparse research undertaken in developing countries such as Kenya where corporate social responsibility and disclosure is doubtless more required seeing the low industrialization levels and high rates of birth, unemployment and poverty that exist (Dobers \& Halme, 2009). Each country has a distinct social structure, dominant issues, institutions and interests, shaped by its unique history and cultural tradition. Specific characteristics of each country may have a role on the disclosure of CSR as can be seen from the international evidence found by Baughn et al., (2007) and Gjølberg (2009).

Companies in low and lower-middle income economies need to understand the link between disclosure of social responsibility practices and financial performance in order to condition their CSR disclosure accordingly (Smith, Adhikari \& Tondkar, 2005). Therefore this paper provides further theoretical and empirical evidence on the influence of disclosure of corporate social responsibility on corporate financial performance from the viewpoint of a lower-middle income economy in Africa. As stated by Elsayed and Wahba (2015) presenting evidence from low income and lower-middle income economies assists in advancing existing theories of corporate finance as well as corporate social responsibility disclosure, as it may not be useful to draw general conclusions from prior studies on organizations that work in well-developed and high-income economies. (Elsayed \& Wahba, 2015).

\subsection{Importance of the Research Problem}

According to the International Financial Reporting Standards (IFRS), the main objective of general purpose financial reports is to provide the financial information about the reporting entity that is useful to existing and potential investors, lenders and other creditors to help them make various decisions (e.g. about trading with debt or equity instruments of a reporting entity). However, as the influence of companies on society has grown globally over the recent 
years, CSR disclosures or reporting in annual reports that is more focused on the impact of sustainability issues on the company itself has gained steam. Companies are increasingly being held accountable to other stakeholders than shareholder and creditor groups the key users of financial information IFSR. These CSR disclosures seek to provide investors with information on how sustainability and CSR issues might impact the company's future financial performance.

Corporate Social Responsibility Disclosure (CSRD) is a "provision of financial and non-financial information relating to an organization's interaction with its physical and social environment, as stated in corporate annual reports or separate social reports" (Guthrie \& Mathew, 1985). It is disclosure of “information relating to a company's activities, aspirations and public image with regards to environmental community, employee and consumer issues" (Gray et al., 2001: 329). The benefit or value of CSRD in annual reports in general and influence on corporate financial performance has long been subject of debate since Friedman (1970) stated that a company's social responsibility is to make profit.

Despite the IFRS non-mandatory obligation of CSR disclosure the number of listed NSE firms that disclosed their CSR activities on their annual reports to shareholders went up from 17\% in 2008 to 95\% in 2014 (Muthuri \& Gilbert, 2015). This increased disclosure of CSR activities are in line with the stakeholder theory of positive relationship but conflicts with the neoclassical goal of companies which views CSR expenditures and disclosures as inappropriate uses of corporate funds (Friedman, 1970). The neoclassical viewpoint holds that social, physical and environmental issues should not be the interest of businesses and CSR engagement and disclosure dilutes the company's primary objective. Given this setting, it is not clear whether CSR disclosure creates or destroys firm value. As an increasing number of firms take up and disclose CSR activities, the analysis of the influence of CSR disclosure on FP is a consequential issue for Kenyan managers who are primarily interested in knowing if and when investment in CSR provides financial benefits to the firm.

The objective of the study was to examine the influence of CSR disclosure on financial performance of companies listed on the Nairobi Securities Exchange (NSE) in Kenya. Primary hypothesis was that CSR disclosure has a positive and significant effect on the financial performance of companies listed on the NSE. A deductive approach to reasoning involving quantitative research was adopted for the study. The implication of using quantitative methods is that the design of all variables, that is, CSR disclosures, control variables and financial performance, that did not exist in quantitative form were converted into quantitative data which could then be analyzed statistically.

Study results are important because they could influence accountants' judgements on inclusion of CSR information in annual reports within a setting that is putting more and more premium on social and environmental engagement by firms. Financial managers can also use the results to structure investment and CSR strategies to maximize future financial returns. For financial managers, CSR is not only an investment decision but also a strategic decision. If CSR actions are better disclosed, firm image and value might improve with it once it is taken to be a process that involves the firm and society. 


\subsection{Literature Review}

There are several possible theoretical explanations regarding why organisations do (or do not) engage in corporate social responsibility reporting, including political economy theory, legitimacy theory and stakeholder theory; in general, the use of particular theory depends upon its scope and the factors studied by the researcher. This study used the stakeholder theory to test the relationship between disclosure of corporate social responsibility and financial performance.

The stakeholder theory recognizes the fact that most firms, if not all, have duties and responsibilities to a large number of stakeholders rather than to shareholders (shareholder wealth maximization) alone (Sweeney \& Coughlan, 2008). Corporate social responsibility disclosure is viewed as a tool that can be employed by the firm to manage or manipulate different stakeholder groups in order to win their approval and support or to distract their disapproval and opposition (Gray et al., 1996).

Stakeholder theory can be viewed from three perspectives, which are, descriptive, instrumental and normative (Donaldson and Preston (1985). Descriptive theory aims to characterize a company, its management and disclosure of CSR to stakeholders while the firm is trying to achieve its corporate goals. Instrumental theory aims to identify the connections between stakeholder management and the achievement of traditional corporate objectives (e.g., profitability, maximization of share price, growth, etc.) (Donaldson \& Preston, 1995). The normative theory views management choices and decisions from a moralistic viewpoint to explain why stakeholders' benefit and concerns rather than the classical goal of shareholder interest should be the overriding firm objective.

In instrumental theory, hypothetical statements of causal effect such as, if $\mathrm{X}$, then $\mathrm{Y}$ or if you want $Y$, then perform $X$ are expressed and determined. Since X, exerts a causal effect on Y, it is an instrument for achieving Y. From the point of view of disclosure of corporate social responsibility and financial performance relationship the logic of instrumental stakeholder theory is as follows: If you want to maximize financial performance, you should satisfy and communicate with key stakeholders; the dissatisfaction through lack of disclosure of information to any stakeholder group can compromise a company's future and affect economic rents (Clarkson, 1995). Disclosure of corporate social responsibility therefore is a precondition for achieving and protecting financial performance.

Using the stakeholder theory, Ruf et al. (2001), examined the association between social performance disclosure and corporate financial performance and found out that changes in disclosure of corporate social performance positively impacted sales growth for current and subsequent year. Similar attempt to test the stakeholder theory was undertaken by Elijido-Ten (2007) in examination of corporate environmental behaviour of Australian listed firms. Her results corroborated stakeholder theory postulation that stakeholder power and strategic posture influence levels of environmental activities. The results suggest a positive relationship between disclosure of social responsibility and financial performance (Uwuigbe \& Egbide, 2012; Ofori \& Hinson, 2014). 
In Australia, Jones et al., (2007) research investigated if there is a positive association between firm financial performance and levels of disclosure of corporate social responsibility by firms. Findings indicated that scores for the corporate social responsibility disclosure index were positively associated with several aspects of firm financial accounting performance measures such as operating cash-flow performance, working capital levels, retained earnings to total assets, interest cover, capital expenditure and total liabilities to total equity while generally negative relationship between disclosure of corporate social responsibility and market measures such as abnormal returns over the study period. Therefore no general conclusion should be drawn about the relationship between disclosure of corporate social responsibility activities and all financial indicators. Similarly, Mahoney and Roberts (2007) study that examined the relationship of corporate social performance to financial performance and institutional ownership found out that there was no significant relationship between the composite corporate social performance measure and either return on assets (ROA) or return on equity (ROE). In Africa, Chetty et al. (2015) results revealed that disclosure of CSR had no significant effect on firms' financial performance while Nkomani's (2013) findings indicated a mixture of results; in some cases a relationship was established, while in other cases there was no significant relationship.

Crisostomo et al., (2011) examined whether there exists a negative correlation between corporate social responsibility disclosure and firm value and accounting performance. While results leaned toward a negative association between CSR disclosures and financial performance in Brazil, overall finding proved no significant effect of CSR disclosure on financial performance. In Tunisia, Elouidani and Zoubir (2015) found out that corporate social responsibility negatively impacts the firm on its stock market performance but positively impacts on its accounting performance. Contrarily, Saleh et al., (2011) found out that corporate social responsibility has positively impacts on financial performance in a statistically significant manner.

In conclusion, the CSRD-CFP association presents some contentious arguments that, along with inconclusive empirical evidence, makes this proposed study on the subject necessary in Kenya and spurs the continuous search for answers.

\subsection{Hypothesis}

From the empirical research, it is clear that the relationship between disclosure of corporate social responsibility and financial performance is either positive, negative or neutral. The positive correlation between disclosure and financial performance reported in the literature may be interpreted to mean that a firm's disclosure of its corporate social responsibility activities would somewhat lead to improved financial performance benefits resultant from the following positive outcomes: Lower operating costs, enhanced brand image and reputation, increased sales and customer loyalty, greater productivity and quality, more ability to attract and retain employees, reduced regulatory oversight, access to capital and product safety and decreased liability.

On the other hand, the negative correlation between disclosure and financial performance reported in the literature may be interpreted to agree with neoclassical objective for 
companies which views corporate social responsibility expenditures and disclosures as inappropriate uses of corporate funds (Friedman, 1970). Critics have also argued that may not be genuinely committed to improving stakeholder engagement but rather disclose stakeholder engagement in reports to in order to avoid bad publicity (Harpreet, 2009, Testa and D'Amato, 2017).

The above conflicting results from conducted research studies points to a dilemma on the actual effect of disclosure of corporate social responsibility activities on financial performance and signify the need for more research to be conducted to resolve the observed contradictions. Thus, this paper seeks to provide empirical evidence from a developing country's perspective to illustrate whether disclosure of corporate social responsibility activities influences positively (or negatively) a firm's financial performance. Thus, the hypothesis of the paper, which is stated as per the positive expectation of the stakeholder theory is:

$H_{01}$ Corporate social responsibility disclosure has a positive and significant effect on the financial performance of companies listed on the Nairobi Securities Exchange in Kenya.

\section{Method}

A post-positivist, deductive approach involving quantitative research methods was adopted for this study. The census consisted of 64 companies (Appendix A), which was obtained from the website of the Nairobi Securities Exchange (NSE). Firms whose annual reports were missing or had delisted during the study period or had a change of name due to restructuring of shareholders' equity were eliminated. After due screening, 18 companies were eliminated (Appendix B), which reduced the sample to 46 companies with 414 firm-year observations.

Data on both corporate social responsibility disclosure and financial performance were collected from companies' annual reports for the years 2007-2016 because they were the most recent firm results that could be easily accessed. CSR disclosure information was collected from the companies' annual reports for the period 2007-2015. Financial data was collected for the period 2008-2016, with a one-year lag behind the CSR data (for example year 2010 CSRD against 2011 financial performance data). Use of time lag conforms to previous research studies (Waddock \& Graves, 1997; Mahoney \& Roberts 2007) which examined the association between CSR disclosure and FP. The rationale is simple: investment in and disclosure of CSR in the current period impacts future rather than current financial performance (Waddock \& Graves, 1997; Mahoney \& Roberts 2007).

\subsection{Variables and Measurements}

\subsubsection{Corporate Social Responsibility Disclosure Index}

CSRD measurement is complicated for two reasons. First, a consensus is missing on the theoretical meaning of the CSR concept (Dahlsrud, 2008). Second, the concept is multidimensional with relatively heterogeneous dimensions (Carroll, 1979). Due to the lack of consensus and complexity of the concept, many different approaches have been used in the literature to measure CSRD. Different approaches could be summarized in the following 
groups: (1) reputation indices; (2) quantitative content analyses; (3) questionnaire-based surveys; and (4) one-dimensional measures. Every measurement to determine the above CSRD has advantages and disadvantages; none is flawless. An adequate measure of corporate social responsibility disclosure must be based on a method of data collection in which the researcher has unrestricted access to data on the full range of activities and disclosure of the firm. This research settled on the quantitative content analysis to measure CSRD.

Riffe, et al (2014) defined quantitative content analysis as "the systematic and replicable examination of symbols of communication, which have been assigned numeric values according to valid measurement rules, and the analysis of relationships involving those values using statistical methods, to describe the communication, draw inferences about its meaning, or infer from the communication to its context, both of production and consumption."

The key advantage of quantitative content analysis method is flexibility for the researcher. A researcher can specify CSR dimensions of interest, collect data according to those dimensions and code data numerically for further use in statistical analyses. The main weaknesses of this approach is the researcher subjectivity embedded in all stages of the research process from the selection of CSR dimensions of interest, collection of data, interpretation of data and coding of data. Another important drawback is reporting bias. CSR reporting is largely voluntary hence many organisations fail to report on their CSR activities even if they do engage in them. Such activities are obviously likely to go undetected by the researcher. Even if the companies do disclose CSR-related data, such data needs to be interpreted carefully as companies often immerse themselves in impressions management to create a more favourable image of their company through biased reporting (Cadez \& Guilding, 2008; Turker, 2009). This is difficult to detect unless the researcher is knowledgeable about the firms' socially responsible actions or if the report has been externally audited.

Ingram and Frazier (1980) state that categories used in content analysis should result from a systematic application of a set of rules to identify exhaustive and mutually exclusive categories. Accordingly, in order to draw valid and reliable inferences from the measurement process, the method suggested by Weber (1985) to create and test a coding scheme was followed. First, the recording units were defined. Ingram and Frazier (1980) suggest the sentence as the unit of analysis, as it is easily identified and is less subject to intercoder variation than other measures, such as words and pages. Second, the categories to be classified were defined to allow an item to be allocated to a particular category. They were intended to be mutually exclusive to avoid confounding of the subsequent statistical analysis. This study primarily employed the content classifications of Hackston and Milne (1996), which are based on earlier schemes developed by Ernst \& Ernst (1978), Guthrie (1982), and Gray et al. (1995b). Accordingly, the dimensions of the content analysis for annual reports broadly embraced the classifications of environment, energy, human resources, community involvement and other.

The third step involved constructing a CSR disclosure checklist. This CSR checklist was then pretested using the annual reports of the largest firms (in terms of capitalization) in each NSE sector. The assumption was that firms with the biggest market capitalization disclosed more 
than lower capitalized firms, and therefore their disclosure items covered CSR activities of smaller firms as well. After pre-testing the CSR checklist, the essential items that constitute a comprehensive CSR disclosure checklist were determined.

The last stage involved computation of the CSR index. The un-weighted disclosure index approach (Rouf 2011) was applied to quantify CSR disclosure level as a dichotomous variable. This means that a disclosure of a CSR item in the annual report as per the CSR checklist scored for a firm "1" while non-disclosure scored it a "0". (Gujarati, 2009). Aggregate score values for CSR disclosure were then computed from all themes or dimensions of CSR disclosures. The CSR disclosure model scoring was additive, and the un-weighted indices were calculated as below to find the sum of the final CSR index (CSRI) for a company.

$$
\text { CSRI }=\sum_{t=1}^{n} d_{i}
$$

where, $C S R I=$ the aggregate disclosures score; $d_{i}=1$ if the item $i$ is disclosed or 0 if it is not disclosed; and $n=$ the maximum of items

While there are a number of measures of reliability in content analysis, Krippendorff's alpha (1980) was used to assess the replicability of the results (Mirfazli, 2008; Perrini \& Tencati 2006; Thompson \& Zakaria, 2004; Vuontisjarvi, 2006). Krippendorff's alpha $(\alpha)$ is a reliability coefficient developed to measure the agreement among coders, observers, raters, judges or measuring instruments drawing distinctions among commonly unordered phenomena or assign computable values to them.

\subsubsection{Financial Performance}

Different researchers have used different financial performance measures in CSRD-FP studies. The financial performance measures most used are either accounting-based measures of profitability or market-based measures. Other previous studies have used both accounting and financial ratios to measure financial performance (Tsoutsoura, 2004; Cochran \& Wood, 1984).

In line with previous studies (Hoskisson et al, 1993, this study used both accounting measures (return on assets (ROA) and return on equity (ROE) and a market value measure (Tobin's Q). These three aspects of financial performance were chosen because they not only represent both accounting and financial measures of financial performance but also they are the current common ratios used in examination of CSRD and FP relationship (Griffin \& Mahon, 1997; Waddock \& Graves 1997; Tsoutsoura, 2004).

Tobin's Q proxies for firm value and is defined as the ratio between the company's market value and its accounting value. Following Chung and Pruitt's (1994) definition Tobin's Q was measured as: $=($ market value of common stock + market value of preference shares + current liability - current asset + long-term debt) / book value of total assets. Elsayed and Paton (2005) used Tobin's Q ratio to examine the effect of environmental disclosure on the firm's 
financial performance.

Return on assets, ROA was measured as (Net Income/ Total Assets). ROA gauges the efficiency of a firm in generating returns from its assets. The relationship between CSRD and ROA has been found to be positive by Moneva and Ortas (2010) and Oeyono et al (2011). Other studies have found no relationship between CSRD and ROA (Dragomir, 2010).

Return on equity, ROE was measured as (Net Income/ Shareholders' Equity). ROE can also be broken down into three separate ratios, as follows:

$$
R O E=\frac{\text { Earnings }}{\text { Sales }} \times \frac{\text { Sales }}{\text { Assets }} \times \frac{\text { Assets }}{\text { Equity }}
$$

The three components, or ratios, can be described (in sequence) as profitability, asset turnover and financial leverage. The ROE can therefore be improved by improving profitability, by using assets more efficiently and by increasing financial leverage. ROE measures how effectively a firm's management uses shareholders' money. Used together, ROA and ROE provide a clearer representation of a company's financial performance than when used alone. Both ROA and ROE financial accounting performance metrics have been used previously in similar studies (Griffin \& Mahon, 1997; Waddock \& Graves, 1997).

\subsubsection{Control Variables}

The study introduced firm size, industry type, leverage of firm and ownership structure of the firm as control variables which may have an influence on the relationship between CSR and firm's FP as has been suggested in other studies (Ullmann, 1985; Griffin \& Mahon, 1997; Waddock \& Graves, 1997; McWilliams \& Siegel, 2000; Clarkson et al., 2011).

The study identified size of firm, type of industry, leverage of firm and ownership structure of the firm as control variables which may confound with CSRD in analysis of influence of CSRD on financial performance (Clarkson et al., 2011). Size of firm (SIZE) was calculated as the natural logarithm of market capitalization. Generally the bigger the firm the more profitable.

The industry variable (INDUS) was defined as manufacturing and non-manufacturing industries. Manufacturing was regarded "more sensitive" and comprised agricultural, construction and allied and manufacturing and allied sectors of the NSE, all associated with lower financial performance (Kolk, 2010; Roberts, 1992). Non-manufacturing was regarded "less sensitive" and was composed of the following sectors: automobiles and accessories, banking, commercial and services, energy and petroleum, insurance, investment, and telecommunication and technology, all associated with better financial performance (Kolk, 2010; Roberts, 1992). The variable was set to "1" if a company was classified as "manufacturing"; otherwise it is non-manufacturing and the variable was set to " 0 ".

Leverage is the use of debt to increase the potential return on investments (Zhu, Yang, An, \& Huang, 2014). High leverage ratios may deter companies from actively participating in socially responsible initiatives and thereby disclose less CSR activities. Leverage is a proxy for risk, depicts management's risk tolerance and higher profits. Leverage (LEV) was 
measured as long-term debt divided by book value of equity (Cormier et al., 2005).

According to Jensen and Meckling (1976) in a widely held company, voluntary disclosure can act as a bonding and monitoring tool reducing agency conflicts between managers and shareholders. Hossain et al. (1994) states that ownership concentration is statistically significant and negatively associated with the extent of voluntary disclosure in annual reports and associated with relatively better financial performance. Ownership structure or concentration (CONC) was measured from data concerning significant shareholdings from 2007-2016 annual reports. If a firm had a majority shareholder (i.e. a shareholder with more than $25 \%$ or more of the voting shares), it was assigned a value of " 1 " and if not it was assigned a " 0 " value.

\subsection{Model and Hypothesis Testing}

Panel data regression was used because it is the most appropriate analysis for this study based on its accorded advantages over conventional cross-sectional and time-series data sets for the period between 2007 and 2016. Key advantages of using panel data are the ability to study dynamic relationships and to model the differences, or heterogeneity, between subjects; key disadvantage is the difficulty in designing the sampling scheme to decrease the issue of subjects leaving the study prior to its completion (attrition) (Frees, 2004). Accordingly, panel data analysis was conducted to estimate the following models:

CSR disclosure and Return on Assets (ROA) testing: $\left(\mathrm{H}_{1}{ }^{\mathrm{A}}\right)$

$Y_{(R O A)}=\beta_{O R O A}+\beta_{1 R O A} C S R I_{j t}+\beta_{2 R O A} S I Z E_{j t}+\beta_{3 R O A} I N D U S_{j t}+\beta_{4 R O A} L E V_{j t}+\beta_{5 R O A} C O N C_{j t}+\varepsilon_{j t}$

CSR disclosure and Return on Equity (ROE) testing: $\left(\mathrm{H}_{1}{ }^{\mathrm{B}}\right)$

$Y_{(R O E)}=\beta_{O R O E}+\beta_{\text {IROE }} C S R I_{j t}+\beta_{2 R O E} S I Z E_{j t}+\beta_{3 R O E} I N D U S_{j t}+\beta_{4 R O E} L E V_{j t}+\beta_{5 R O E} C O N C_{j t}+\varepsilon_{j t}$

CSR disclosure and Tobin's Q (TBQ) testing: $\left(\mathrm{H}_{1}{ }^{\mathrm{C}}\right)$

$$
Y_{(T B Q)}=\beta_{0 T B Q}+\beta_{1 T B Q} C S R I_{j t}+\beta_{2 T B Q} S I Z E_{j t}+\beta_{3 T B Q} I N D U S_{j t}+\beta_{4 T B Q} L E V_{j t}+\beta_{5 T B Q} C O N C_{j t}+\varepsilon_{j t}
$$

\subsection{Specification Tests}

The following tests were adopted to identify the best model:

\subsubsection{Examining group effects (f tests: Pooled or FEM)}

This test result was to show whether there are fixed group effects or not (Park 2005). The null hypothesis is shown as:

$$
H_{0}: \mu_{1}=\mu_{n-1}
$$

If the null hypothesis is rejected, the fixed group effect is better than the POLS model. A higher F-value shows a lower $p$-value. The fixed group effect model is then accepted (Park 2005).

\subsubsection{Hausman test: FEM or REM}

The Hausman specification test is to choose between fixed (FEM) and random (REM) effects 
models to ensure that the more applicable model similarly gives consistent results. It is alright to use random effects if they are (insignificant $p$-value, Prob>chi2 larger than .05). However, if $p$-value is significant, use fixed effects.

\subsubsection{The Breusch and Pagan Lagrange Multiplier Test}

The Breusch-Pagan LM test helps to decide between a random effects regression and a simple or pooled OLS regression. The null hypothesis in the LM test was that variances across entities was zero or no random effects exist in the model $\left(\mathrm{H}_{0}: \sigma^{2}{ }_{i t}=0\right)($ Gujarati, 2009). If the null hypothesis is rejected, then random effects is appropriate over the pooled OLS model. If the null hypothesis is accepted, the pooled OLS model is more suitable than random effects.

\section{Results}

\subsection{Descriptive Analysis}

As part of the procedure for data analysis and interpretation, descriptive statistics are presented in Table 1 for both the outcome and explanatory variables required for analysis. Each variable was examined to determine the distribution, central tendency and the dispersion of the variables for all firms in the selected sample.

When it comes to the major variables, ROA had a mean of 7.021318, a standard deviation of 12.10162. Both mean and standard deviation for ROA are lower than for ROE and TBQ because the longer the period over which ROA is measured the less variable it is likely to be (subject to major strategic shifts in firms' direction and performance). The minimum value was negative 30.91 which clearly means that there are some firms which made losses and the maximum value was positive 65.9 an indicator of positive profits made over the study period.

Average ROE was 12.53096 and the standard deviation recorded was 78.36588. ROE standard deviation depicts higher dispersion than ROA standard deviation. ROE dispersion provides an aggregate measure of co-movement in the NSE portfolio for the time period under study and carries reliable information regarding the state of the economy (economic expansions and recessions). ROE is a measure of efficiency; high ROE's suggest firm's ability to generate profits without needing as much equity capital to finance their operations.

Tobin's Q for all firms under study recorded a mean of 85.19237 and a standard deviation of 561.5627 while the minimum value was -0.2 and a maximum value of 4913.61 . The highest standard deviation for financial performance variables was the Tobin's Q (561.5627), suggesting that the difference among the firms was highest in this financial performance indicator. Generally, firms that disclose CSR more are larger, more profitable and higher in TBQ.

The mean and standard deviation for the CSR Index is 0.4790107 and 0.3024354 respectively; minimum is 0 and maximum 1 . The control variable SIZE measured by the natural logarithm of market capitalization, had an average of 9.68672 (antilog: Sh. 4,860,937,084) with a standard deviation of 0.9288673. The minimum value was 6.134241 (antilog: Sh. 1,362,200) and the maximum score was 11.4032 (antilog: Sh. 253,046,304,946). From the stakeholder 
theory it is expected that CSR disclosure positively affects firm performance because it helps firms gain positive stakeholder responses. The study depicts firms listed on the NSE had good market capitalization as indicated by a mean of 9.68672 (antilog: Sh. 4,860,937,084).

Industry was measured by scores allocated, where a score of "1" was allocated for manufacturing the variable and non-manufacturing and the variable was set to " 0 ". The study recorded a mean of 0.4 and the standard deviation was 0.4905039 which depicts a least dispersion between the manufacturing proxied by 1 and the non-manufacturing measured using a score of 0 . A mean of 0.4 means that on average most firms are in the non-manufacturing category. It is expected that industry membership is positively and significantly correlated with CSR disclosure (Monteiro \& Guzman, 2010). Manufacturing is regarded as more sensitive and non-manufacturing less sensitive to CSR disclosure. The maximum value was 1 and the minimum stands at 0 . The average leverage ratio 149.3729 highlights the likelihood of NSE listed companies to finance assets and or operations by use of liabilities instrument. Leverage affects shareholders' returns. The standard deviation is 122.7223 while minimum and maximum values recorded are 0 and 610.66 respectively.

Table 1. Descriptive Statistics

\begin{tabular}{|l|l|l|l|l|}
\hline & Mean & Sd & Min & Max \\
\hline Csri & .4790107 & .3024354 & 0 & 1 \\
\hline Roa & 7.021318 & 12.10162 & -30.91 & 65.9 \\
\hline Roe & 12.53096 & 78.36588 & -1006.74 & 625.62 \\
\hline Tbq & 85.19237 & 561.5627 & -.2 & 4913.61 \\
\hline Size & 9.68672 & .9288673 & 6.134241 & 11.4032 \\
\hline Indus & .4 & .4905039 & 0 & 1 \\
\hline Lev & 149.3729 & 122.7223 & 0 & 610.66 \\
\hline
\end{tabular}

\subsection{Reliability Measure}

Before analysis the results of the impact of different Corporate Social Responsibility Disclosure (CSRD) on the financial performance of the firms listed in the Nairobi Securities Exchange, it was necessary to establish the consistency of how CSRD is measured. To this end, the study computed the Krippendorff's alpha (Krippendorff, 1980). The results of the Krippendorff alpha in this study show high reliability over all the years of the period of study as well as all dimensions of CSRD and the overall CSRD.

Table 2. Reliability Measure: Krippendorff's Alpha Results

\begin{tabular}{|l|l|l|l|l|}
\hline Overall & 0.9540 & 0.9767 & 1 & 0.9767 \\
\hline
\end{tabular}




\subsection{Multicollinearity}

Table 3. Correlation Matrix for the Explanatory Variables

\begin{tabular}{|l|l|l|l|l|}
\hline & Aggregate Disclosure Score & Firm Size & Industry & Leverage \\
\hline Aggregate Disclosure Score & 1 & & & \\
\hline Firm Size & 0.678 & 1 & & \\
\hline Industry & -0.300 & -0.259 & 1 & \\
\hline Leverage & 0.282 & 0.369 & -0.210 & 1 \\
\hline
\end{tabular}

This test was done in order to check for the presence of multicollinearity. The matrix of correlation between the explanatory variables is computed and the results are summarized in Table 3. In terms of the control variables firm size, industry type, and leverage, there is no issue of multicollinearity, as the correlation does not exceed 0.70 in the worst cases.

\subsection{Hausman Test}

Table 4. Hausman Results

\begin{tabular}{|l|l|l|l|}
\hline Dependent variable & Chi Square value & $\mathrm{p}$ value & Model to choose \\
\hline ROA & 36.53 & 0.4798 & $\mathrm{RE}$ \\
\hline ROE & 0.40 & 0.9392 & $\mathrm{RE}$ \\
\hline TBQ & 4.04 & 0.2568 & $\mathrm{RE}$ \\
\hline
\end{tabular}

The Hausman tests for the three models are summarized in tables 4. Interpretation of the results is that if the $p$-value is significant $(p<0.05)$ then use fixed effects, if not $(p>0.05)$ use random effects (Greene, 2018). Based on the interpretation of results, the random effects model was adopted for the panel analysis.

\subsection{Analysis}

The influence of CSRD on financial performance was estimated using the following models that captured the firms' specific effects in the error component.

$$
\begin{aligned}
& Y_{(R O A) i t}=\beta_{0 R O A}+\beta_{1 R O A} C S R I_{i t}+\beta_{2 R O A} S_{I Z E_{i t}}+\beta_{3 R O A} I N D U S_{i t}+\beta_{4 R O A} L E V_{i t} \\
& +\beta_{5 R O A} C_{O N C} C_{i t}+\left(\epsilon_{(R O A) i t}+\eta_{(R O A) i}\right) \\
& Y_{(R O E) i t}=\beta_{0 R O E}+\beta_{1 R O E} C S R I_{i t}+\beta_{2 R O E} S I Z E_{i t}+\beta_{3 R O E} I N D U S_{i t}+\beta_{4 R O E} L E V_{i t} \\
& +\beta_{5 R O E} C O N C_{i t}+\left(\epsilon_{(R O E) i t}+\eta_{(R O E) i}\right) \\
& Y_{(T B Q) i t}=\beta_{0 T B Q}+\beta_{1 T B Q} C S R I_{i t}+\beta_{2 T B Q} S I Z E_{i t}+\beta_{3 T B Q} I N D U S_{i t}+\beta_{4 T B Q} L E V_{i t} \\
& +\beta_{5 T B Q} C O N C_{i t}+\left(\epsilon_{(T B Q) i t}+\eta_{(T B Q) i}\right)
\end{aligned}
$$

Given the error component feature of these regressions the generalized least squares estimation was used instead of the ordinary least squares estimation. The results indicate that CSRD is positive but not statistically significant in explaining the variation in firms' ROA. For ROE, CSRD is negative but not statistically significant. The results are presented in the following table 5 . 
Table 5. Overall CSRI for Random Effect Model

\begin{tabular}{|l|l|l|l|l|}
\hline & ROA & ROE & TBQ \\
\cline { 2 - 5 } Csri & 0.0146 & -10.22 & -15.11 \\
\hline & $(0.00)$ & $(-0.59)$ & $(-0.18)$ \\
\hline Size & $3.672^{* *}$ & $24.88^{* * *}$ & $57.88^{* *}$ \\
\hline & $(2.93)$ & $(4.28)$ & $(3.13)$ \\
\hline Indus & $6.548^{* *}$ & 8.014 & 224.9 \\
\hline & $(2.71)$ & $(0.98)$ & $(1.39)$ \\
\hline Lev & $-0.0271^{* * *}$ & $-0.0882^{* *}$ & 0.00151 \\
\hline & $(-4.52)$ & $(-2.62)$ & $(0.02)$ \\
\hline Conc & 0 & 0 & 0 \\
\hline & $()$. & $()$. & $()$. \\
\hline cons & $-27.31^{*}$ & $-213.7^{* * *}$ & $-563.2^{* *}$ \\
\hline & $(-2.41)$ & $(-4.19)$ & $(-2.73)$ \\
\hline N & 414 & 414 & 414 \\
\hline \multirow{4}{*}{$t$ statistics in parentheses } & \multicolumn{4}{|l}{} \\
\cline { 2 - 5 } & & \multicolumn{4}{|l}{}
\end{tabular}

$t$ statistics in parentheses

$* \mathrm{p}<0.05, * *<0.01, * * * \mathrm{p}<0.001$

Table 6 provides the results of regressing return on assets on an overall corporate social responsibility disclosure index, the firm's size, the industry type, and the firm's leverage. The results indicate that the corporate social responsibility disclosure is positive but not statistically significant in explaining the variation in firms' return on assets. The firm size and the industry type variables are positive and statistically significant effect on return on assets; while the leverage has a negative and statistically significant effect on firms' return on assets. On the other hand, the variance due to the difference between firms contributes more than $42 \%$ to the overall variance.

Table 6. Results of CSR Disclosure for ROA

\begin{tabular}{|l|l|l|l|l|}
\hline & \multicolumn{3}{|c|}{ Return on Assets } \\
\hline & Estimate & Std.error & t-value & $p$-value \\
\hline Aggregate Disclosure Score & 0.0146 & 4.1902 & 0.0035 & 0.9972 \\
\hline Firm Size & $3.6719^{* *}$ & 1.2544 & 2.9272 & 0.0034 \\
\hline Industry & $6.5481^{* *}$ & 2.4119 & 2.7149 & 0.0066 \\
\hline Leverage & $-0.0271^{* * *}$ & 0.0060 & -4.5195 & 0.0000 \\
\hline Constant & $-27.3052^{*}$ & 11.3509 & -2.4055 & 0.0161 \\
\hline Observations & 414 & & & \\
\hline R2 within & 0.0430 & & & \\
\hline R2 between & 0.3058 & & & \\
\hline R2 overall & 0.1851 & & & \\
\hline $\begin{array}{l}\text { Breusch and Pagan Lagrange Multiplier Test } \\
\text { Breusch and Pagan Lagrange Multiplier Test } \\
\text { Hausman Test of Consistency of Random Effects } \\
\text { Hausman Test of Consistency of Random Effects }\end{array}$ & $\begin{array}{l}\left.x^{2}{ }_{1}\right)=248.97 \\
\left.p-\text { value }<{ }_{3}\right)=3.17 \\
\mathrm{p}-\text { value }=0.0000\end{array}$ & \\
\hline
\end{tabular}

The Breusch and Pagan Lagrange Multiplier (BP LM) test for random effects rejects the null hypothesis that the variance of the specific effect is zero is rejected at the $1 \%$ significance level. This means that the random effects are statistically more efficient than the pooled 
model. Furthermore, the Hausman test fails to reject the null hypothesis that the random effects model is as consistent as the fixed effects model, leading to conclude that the random effects model is superior to fixed effects model. Table 7 gives the results of the random effects estimation of the second regression, where the dependent variable is return on equity.

Table 7. Results of the Overall CSR Disclosure for ROE

\begin{tabular}{|l|l|l|l|l|}
\hline & Estimate & Std.error & t-value & $p$-value \\
\hline Aggregate Disclosure Score & -10.2153 & 17.2627 & -0.5918 & 0.5540 \\
\hline Firm Size & $24.8802^{* * * *}$ & 5.8170 & 4.2772 & 0.0000 \\
\hline Industry & 8.0144 & 8.1961 & 0.9778 & 0.3282 \\
\hline Leverage & $-0.0882^{* * *}$ & 0.0337 & -2.6177 & 0.0089 \\
\hline Constant & $-213.7411^{* * *}$ & 51.0609 & -4.1860 & 0.0000 \\
\hline$R^{2}$ within & 0.0070 & & & \\
\hline$R^{2}$ between & 0.3699 & & \\
\hline Breusch and Pagan Lagrange Multiplier Test & $\mathrm{x}\left({ }_{1}\right)=0.0033$ & \\
\hline Breusch and Pagan Lagrange Multiplier Test & $\mathrm{p}-$ value $=0.4903$ & \\
\hline Hausman Test of Consistency of Random Effects & $\mathrm{x}\left({ }_{3}\right)=0.40$ \\
\hline Hausman Test of Consistency of Random Effects & $\mathrm{p}-$ value $=0.9399$ \\
\hline
\end{tabular}

As with other models, the return on equity regression gives the worst results compared with the return to assets and ROE. Hence, the corporate social responsibility disclosure index is negative but not statistically significant. Similarly, the industry type dummy variable is has a positive but not statistically significant effect; while the firms' size affect positively and statistically significantly the firms' return on equity. For the leverage variable, the coefficient estimate indicates a negative and statistically significant relationship between firms' leverage and their return on equity.

The Breusch and Pagan Lagrange Multiplier test for random effects selects the pooled effect over the random effects; while the Hausman test results favors the random effects model over the fixed effects model. Table 8 gives the results of the random effects estimation of the third regression, where the dependent variable is Tobin's Q.

Table 8. Results of CSR Disclosure for TBQ

\begin{tabular}{|l|l|l|l|l|}
\hline & Estimate & Std.error & $t$-value & $p$-value \\
\hline Aggregate Disclosure Score & -15.1102 & 82.0138 & -0.1842 & 0.8538 \\
\hline Firm Size & $57.8806^{* *}$ & 18.4973 & 3.1291 & 0.0018 \\
\hline Industry & 224.9358 & 162.1698 & 1.3870 & 0.1654 \\
\hline Leverage & 0.0015 & 0.0742 & 0.0203 & 0.9838 \\
\hline Constant & $-563.1609^{* *}$ & 206.4440 & -2.7279 & 0.0064 \\
\hline Observations & 414 & & & \\
\hline $\mathrm{R}^{2}$ within & 0.0237 & & & \\
\hline $\mathrm{R}^{2}$ between & 0.0608 & & & \\
\hline $\mathrm{R}^{2}$ overall & 0.0599 & & \\
\hline $\begin{array}{l}\text { Breusch and Pagan Lagrange Multiplier Test } \\
\text { Breusch and Pagan Lagrange Multiplier Test } \\
\text { Hausman Test of Consistency of Random Effects } \\
\text { Hausman Test of Consistency of Random Effects }\end{array}$ & $\begin{array}{l}\mathrm{p}\left({ }_{1}\right)=1557.17 \\
\mathrm{x}\left({ }_{3}\right)=5.08\end{array}$ \\
\hline
\end{tabular}


The results indicate a negative but not statistically significant relationship between the corporate social responsibility disclosure and Tobin's Q. Furthermore, only the firm's size variable is statistically significant. The Breusch and Pagan Lagrange multiplier test highly rejects the pooled model in favor of the random effects model. In addition, Hausman test fails to reject the null hypothesis that the random effects model parameter estimates are consistent.

In conclusion, the overall corporate social responsibility disclosure does not statistically impact any of the three performance measures. The Breusch Pagan Lagrange Multiplier tests favour the random effects model over the pooled model for the return on assets, return on equity and the Tobin's Q. The Hausman test for consistency of the random effects fails to reject the consistency of the random effects. For completeness, the side by side comparison of the three regressions is provided in Table 9.

Table 9. Results for the Overall CSR Disclosure

\begin{tabular}{|c|c|c|c|c|c|c|}
\hline & $\begin{array}{l}\text { Return on } \\
\text { Estimate } \mathrm{t}-\text { value }\end{array}$ & Assets & $\begin{array}{l}\text { Return on Equity } \\
\text { Estimate } \mathrm{t} \text { - value }\end{array}$ & & $\begin{array}{ll}\text { Tobin } & \mathrm{Q} \\
\text { Estimate } & \end{array}$ & t value \\
\hline $\begin{array}{l}\text { Aggregate } \\
\text { Disclosure Score }\end{array}$ & 0.0146 & 0.00 & -10.22 & -0.59 & -15.11 & -0.18 \\
\hline Firm Size & $3.672 * *$ & 2.93 & $24.88 * * *$ & 4.28 & $57.88 * *$ & 3.13 \\
\hline Industry & $6.548 * *$ & 2.71 & 8.014 & 0.98 & 224.9 & 1.39 \\
\hline Leverage & $-0.0271 * * *$ & -4.52 & $-0.0882 * *$ & -2.62 & 0.00151 & 0.02 \\
\hline Ownership Structure & & & & & 0 & \\
\hline Constant & $-27.31 *$ & -2.41 & $-213.7 * * *$ & -4.19 & $-563.2 * *$ & -2.73 \\
\hline Observations & 414 & & 414 & & 414 & \\
\hline R2 within & 0.0430 & & 0.0070 & & 0.0237 & \\
\hline R2 between & 0.3058 & & 0.3699 & & 0.0608 & \\
\hline R2 overall & 0.1851 & & 0.0646 & & 0.0599 & \\
\hline $\begin{array}{l}\text { BP Lagrange } \\
\text { Multiplier Test }\end{array}$ & $X 2(1)=248.97$ & & $\mathrm{X} 2(1)=0.0033$ & & $\begin{array}{l}X 2(1)= \\
1557.17\end{array}$ & \\
\hline $\begin{array}{l}\text { BP Lagrange } \\
\text { Multiplier Test }\end{array}$ & $\begin{array}{l}\mathrm{p}-\text { value }< \\
0.0000\end{array}$ & & $\begin{array}{l}\mathrm{p}-\text { value }= \\
0.4903\end{array}$ & & $\begin{array}{l}\mathrm{p}-\text { value }< \\
0.0000\end{array}$ & \\
\hline Hausman Test & $* 23)=3.17$ & & $\mathrm{X} 23)={ }^{\circ} .40$ & & $\mathrm{x} 23)=5.08$ & \\
\hline Hausman Test & $\begin{array}{l}\mathrm{p}-\text { value }= \\
0.3664\end{array}$ & & $\begin{array}{l}\mathrm{p} \text {-value } \quad= \\
0.9399\end{array}$ & & $\begin{array}{l}\mathrm{p}-\text { value }= \\
0.1657\end{array}$ & \\
\hline
\end{tabular}

$t$-statistics in second column

$* p<0.05, * * p<0.01, * * * p<0.001$

\section{Discussion}

A comparison between the above results and findings from other studies presents some commentary. Firstly, if firm performance is measured by ROA, then the results concurs with those of McWilliams and Siegel (2001), as well as those of Gil et al. (2009), and García-Castro et al. (2010). Inclusion of variables that cover research and development and advertising intensity (McWilliams \& Siegel, 2000) into the CSRD index has been shown to have an effect on firm financial performance and would therefore affect the results of the model. García-Castro et al. (2010) supports the importance of including some measure of management quality in this type of model as management quality is a factor that is likely 
associated with the disclosure of CSR practices. When using ROE and TBQ as measures of performance, the studies of Aupperle et al. (1985), Gil et al. (2009) corroborate the results found here.

It can be argued that CSR disclosures are in part endogenously determined by the firm's environment which differs across firms in observable and unobservable ways. Firm-specific factors which were not considered in the model for this study such as research and development and management talent and firm culture could drive specific CSR activities and disclosures or policies. In econometric terms, failing to account for firm-specific characteristics could bias the correlation between CSRD and financial performance if these characteristics are significantly correlated with the proxies for CSRD.

\section{Conclusion}

With regard to the influence of CSRD on FP measured using ROA, the CSRD index is positive but not statistically significant in explaining the variation in firms ROA. With ROE, the CSRD index is negative but not statistically significant. For TBQ results indicate a negative but not statistically significant relationship between the CSRD index and Tobin's Q. Since CSRD does not statistically impact any of the three financial performance measures it is concluded that the hypothesis that the disclosure has a positive impact on financial performance is rejected. Thus the neutrality of the influence of CSRD on financial performance or the bottom line is verified. In other words, these findings point to a neutral effect of CSRD on the financial performance for NSE listed firms in Kenya. The conclusion therefore is that the relationship between corporate social responsibility disclosure and financial performance as a natural phenomenon cannot be explained solely by the prediction that exists under the stakeholder theory.

According to Whetten, et al. (2014) a theory can be challenged on the basis of its assumptions being proved to be unrealistic. Under the stakeholder theory, stakeholders other than shareholders are assumed to have the power to affect the firm's performance. It is also assumed that there exists a "contract" for the relationships between the firm and its stakeholders. In reality, both assumptions are oversimplifications. First, shareholders effectively and to the exclusion of other stakeholders control firms traded in the NSE and their primary goal is maximization of the value of their shares; it seems therefore that CSR disclosures made in the annual reports are to create a more favourable image of companies involved through biased reporting and as a result of herd mentality or institutional isomorphism. Unlike in the developed countries, few stakeholders in the NSE are powerful or vocal enough to attempt to exert their control on firms. Second and concerning the assumed "contract" between the firm and its stakeholders, it is a fact that there exists no contract between the two parties. Managers instead of fulfilling their duties as "contracting agents" basically act in their own interests and those of the shareholders. For these two reasons, the stakeholder theory failed to specify how managers can make the necessary tradeoffs among the competing interest of the different stakeholders within the practical setting of the NSE making the theory externally inconsistent.

In terms of theoretical contribution therefore, this study proposes that unequal controlling 
strengths of different stakeholders should be assumed and captured under the stakeholder theory in order for managers to be able to make the necessary tradeoffs among competing stakeholders. The modification of the theory in this manner would make it possible for financial managers to make purposeful disclosure decisions within the national context of developing countries such as Kenya. These stakeholders should be able to affect financial performance and secondly have a "real contract" of some sort with the firms, such as debtholders.

Empirically, the neutral overall CSRD-FP relationship results imply that firms are free to disclose CSR activities without the worry whether they will be able to accrue financial benefits in the short or long run. The neutral CSRD-FP relationship results does not suggest that firms' involvement in CSR activities is a waste of financial resources. When the CSRD is decomposed into employees, environment, community, education, and health dimensions, only the environmental dimension of corporate social responsibility disclosure has a positive and statistically significant impact on the return on assets variable. This implies that investment in environmentally friendly projects positively impacts ROA.

The paper recommends that calls from some stakeholders that CSR disclosure should continue to be voluntary in Kenya; calls from some stakeholders for mandatory disclosures should not be heeded. Secondly, financial managers should ignore pressure from stakeholders to pursuit and disclose more CSR activities because CSR does not add value to the firm.

This paper can be improved upon by using more years' data and a larger sample size. This would increase the reliability of the results. Secondly, the study focused on NSE listed companies in Kenya. Future research could involve more developing countries in East Africa or Africa. Thirdly, CSRD disclosure metrics were limited by the lack of firm-specific information such as research and development intensity and management quality. Richer disclosure measures may reveal patterns this research was not able to capture. Lastly, paper was limited to three finance performance indicators, which are ROA, ROE and TBQ. Use of more financial performance indicators, both accounting-based and market-based performance may yield different results.

\section{References}

Abbott, W. F., \& Monsen, R. J. (1979). On the Measurement of Corporate Social Responsibility: Self-Reported Disclosures as a Method of Measuring Corporate Social Involvement. Academy of Management Journal, 22(3), 501-515.

https://doi.org/10.5465/255740

Aupperle, K. E., Carroll, A. B., \& Hatfield, J. D. (1985). An Empirical Investigation of the Relationship Between Corporate Social Responsibility and Profitability. Academy of Management Journal, 28, 446-463. https://doi.org/10.2307/256210

Barton, S. L., Hill, N. C., \& Sundaram, S. (1989). An empirical test of stakeholder theory predictions of capital structure. Financial Management, 18(1), 36-44.

https://doi.org/10.2307/3665696 
Baughn, C. C., Bodie, N. L., \& Mcintosh, J. C. (2007). Corporate Social and Environmental Responsibility in Asian Countries and Other Geographical Regions. Corporate Social Responsibility and Environmental Management, 14(4), 189-205.

https://doi.org/10.1002/csr.160

Bradbury, M. E. (1992). Voluntary Disclosure of Financial Segment Data: New Zealand Evidence. Accounting \& Finance, 32(1), 15-26.

https://doi.org/10.1111/j.1467-629X.1992.tb00174.x

Carroll, A. B., \& Shabana, K. M. (2010). The Business Case for Corporate Social Responsibility: A Review of Concepts, Research and Practice. International Journal of Management Reviews, 12(1), 85-105. https://doi.org/10.1111/j.1468-2370.2009.00275.x

Chetty, S., Naidoo, R., \& Seetharam, Y. (2015). The Impact of Corporate Social Responsibility on Firms' Financial Performance in South Africa. Contemporary Economics, 9(2), 193-214. https://doi.org/10.5709/ce.1897-9254.167

Chow, C. W., \& Wong-Boren, A. (1987). Voluntary Financial Disclosure by Mexican Corporations. The Accounting Review, 62(3), 533-541.

Clarke, J., \& Gibson-Sweet, M. (1999). The Use of Corporate Social Disclosures in the Management of Reputation and Legitimacy: A Cross Sectoral Analysis of UK Top 100 Companies. Business Ethics: A European Review Business Ethics, 8(1), 5-13. https://doi.org/10.1111/1467-8608.00120

Clarkson, M. B. E. (1995). A stakeholder framework for analyzing and evaluating corporate social performance. Academy of Management Review, 20, 92-117.

https://doi.org/10.5465/amr.1995.9503271994

Cornell, B., \& Shapiro, A. C. (1987). Corporate Stakeholders and Corporate Finance. Financial Management, 16, 5-14. https://doi.org/10.2307/3665543

Cowen, S., Ferreri, L., \& Parker, L. (1987). The impact of corporate characteristics on social responsibility disclosure: A typology and frequency based analysis. Accounting, Organizations and Society, 12(2), 111-122. https://doi.org/10.1016/0361-3682(87)90001-8

Crisóstomo, V. L., Freire, F. S., \& Vasconcellos, F. C. (2011). Corporate Social Responsibility, Firm Value and Financial Performance in Brazil. Social Responsibility Journal, 7(2), 295-309. https://doi.org/10.1108/17471111111141549

Cullen, L., \& Christopher, T. (2002). Governance disclosures and firm characteristics of listed Australian mining companies. International Journal of Business Studies, 10(1), 37-58.

Deegan, C. (2002). The Legitimising Effect of Social and Environmental Disclosures - A Theoretical Foundation. Accounting, Auditing \& Accountability Journal, 15(3), 282-311. https://doi.org/10.1108/09513570210435852

Dhaliwal, D., Li, O. Z., Tsang, A. H., \& Yang, Y. G. (2011). Voluntary non-financial disclosure and the cost of equity capital: The case of corporate social responsibility reporting. 
The Accounting Review, 86(1), 59-100. https://doi.org/10.2308/accr.00000005

Dobers, P., \& Halme, M. (2009). Corporate Social Responsibility and Developing Countries. Corporate Social Responsibility and Environmental Management, 16(5), 237-249.

https://doi.org/10.1002/csr.212

Donaldson, T., \& Preston, L. (1995). The Stakeholder Theory of the Corporation: Concepts, Evidence, and Implications. The Academy of Management Review, 20(1), 65-91. https://doi.org/10.5465/amr.1995.9503271992

Elijido-Ten, E. (2007). Applying stakeholder theory to analyze corporate environmental performance: Evidence from Australian listed companies. Asian Review of Accounting, 15(2), 164-184. https://doi.org/10.1108/13217340710823378

Elouidani, A., \& Zoubir, F. (2015). Corporate social responsibility and financial performance. African Journal of Accounting, Auditing and Finance, 4(1), 74-85.

https://doi.org/10.1504/AJAAF.2015.071749

Frees, E. W. (2004). Longitudinal and Panel Data: Analysis and Applications in the Social Sciences. Cambridge (UK): Cambridge University Press.

https://doi.org/10.1017/CBO9780511790928

Friedman, M. (1970). The Social Responsibility of Business Is to Increase Its Profits. Corporate Ethics and Corporate Governance, 173-178.

https://doi.org/10.1007/978-3-540-70818-6_14

Garcia-Castro, R., Arino, M. A., \& Canela, M. A. (2010). Does social performance really lead to financial performance? Accounting for endogeneity. Journal of Business Ethics, 92(1), 107-126. https://doi.org/10.1007/s10551-009-0143-8

Gil, M. A., Giner, F., \& Gríful, C. (2009). Benchmarking corporate social responsibility within Spanish companies. International Advances in Economic Research, 15(2), 207-225. https://doi.org/10.1007/s11294-008-9190-7

Gjølberg, M. (2009). The Origin of Corporate Social Responsibility: Global Forces or National Legacies?. Socio-Economic Review, 7(4), 605-637.

https://doi.org/10.1093/ser/mwp017

Gray, R., Javad, M., Power, D. M., \& Sinclair, C. D. (2001). Social and Environmental Disclosure and Corporate Characteristics: A Research Note and Extension. Journal of Business Finance Accounting, 28(3-4), 327-356. https://doi.org/10.1111/1468-5957.00376

Gray, R. H., Owen, D. L., \& Adams, C. (1996). Accounting and Accountability: Changes and Challenges in Corporate Social and Environmental Reporting. London: Prentice Hall.

Greene, W. H. (2018). Econometric analysis. Upper Saddle River, N.J.: Prentice Hall.

Gregory, A., Tharyan, R., \& Whittaker, J. (2014). Corporate Social Responsibility and Firm Value: Disaggregating the Effects on Cash Flow, Risk and Growth. Journal of Business Ethics, 124(4), 633-657. https://doi.org/10.1007/s10551-013-1898-5 


\section{Mll Macrothink}

Business and Economic Research ISSN 2162-4860 2020, Vol. 10, No. 3

Griffin, J. J., \& Mahon, J. F. (1997). The Corporate Social Performance and Corporate Financial Performance Debate: Twenty-Five Years of Incomparable Research. Business \& Society, 36(1), 5-31. https://doi.org/10.1177/000765039703600102

Guthrie, J. E., \& Mathews, M. R. (1985). Corporate social accounting in Australasia. Research in Corporate Social Performance and Policy, 7, 251-77.

Hamid, F. Z. A. (2004). Corporate Social Disclosure by Banks and Finance Companies: Malaysian Evidence. Corporate Ownership \& Control, 1(4), 118-130.

https://doi.org/10.22495/cocv1i4p10

Haniffa, R. M., \& Cooke, T. E. (2005). The impact of culture and governance on corporate social reporting. Journal of Accounting and Public Policy, 24(5), 391-430.

https://doi.org/10.1016/j.jaccpubpol.2005.06.001

Harpreet, S. B. (2009). Financial Performance and Social Responsibility: Indian Scenario. [Online] Available: https://ssrn.com/abstract=1496291

Jenkins, H., \& Yakovleva, N. (2006). Corporate Social Responsibility in the Mining Industry: Exploring Trends in Social and Environmental Disclosure. Journal of Cleaner Production, 14(3-4), 271-284. https://doi.org/10.1016/j.jclepro.2004.10.004

Jones, S., Frost, G., Loftus, J., \& van der Laan, S. (2007), An Empirical Examination of the Market Returns and Financial Performance of Entities Engaged in Sustainability Reporting. Australian Accounting Review, 17(43), 78-87.

https://doi.org/10.1111/j.1835-2561.2007.tb00456.x

Krippendorff, K. (1980). Content Analysis: An Introduction to its Methodology. Beverly Hills: Sage.

Line, M., Hawley, H., \& Krut, R. (January 01, 2002). The Development of Global Environmental and Social Reporting. Corporate Environmental Strategy, 9(1), 69-78. https://doi.org/10.1016/S1066-7938(01)00159-2

Mahoney, L., \& Roberts, R. W. (2007). Corporate Social Performance, Financial Performance and Institutional Ownership in Canadian firms. Accounting Forum, 31(3), 233-253. https://doi.org/10.1016/j.accfor.2007.05.001

Margolis, J. D., \& Walsh, J. P. (2003). People and Profits?: The Search for a Link Between a Company's Social and Financial Performance. Mahwah, NJ: Lawrence Erlbaum Associates.

McWilliams, A., \& Siegel, D. (2000). Corporate Social Responsibility and Financial Performance: Correlation or Misspecification? Strategic Management Journal, 21, 603-609. https://doi.org/10.1002/(SICI)1097-0266(200005)21:5<603::AID-SMJ101>3.0.CO;2-3

Mishra, S., \& Modi, S. (2013). Positive and Negative Corporate Social Responsibility, Financial Leverage, and Idiosyncratic Risk. Journal of Business Ethics, 117(2), 431-448. https://doi.org/10.1007/s10551-012-1526-9

Muthuri, J. N., \& Gilbert, V. (2015). An Institutional Analysis of Corporate Social 
Responsibility in Kenya. Journal Bus Ethics Journal of Business Ethics, 98(3), 467-483. https://doi.org/10.1007/s10551-010-0588-9

Mwanyasi, R. (2017, August 1). Why Every Firm Should Give Back to Community. Business Daily. [Online] Available:

http://www.businessdailyafrica.com/analysis/Why-every-firm-should-give-back-to-communit y/539548-4041050-twxbdc/index.html

Ness, K. E., \& Mirza, A. (1991). Corporate Social Disclosure: A Note on a Test of Agency Theory. The British Accounting Review, 23(3), 211-217.

https://doi.org/10.1016/0890-8389(91)90081-C

Neu, D., Warsame, H., \& Pedwell, K. (1998). Managing public impressions: Environmental disclosures in annual reports. Accounting, Organizations and Society, 23(3), 265-282. https://doi.org/10.1016/S0361-3682(97)00008-1

Nkomani, S. (2013). Corporate Social Responsibility and Financial Performance: The Johannesburg Stock Exchange Top 100. Unpublished dissertation, University of Pretoria. [Online] Available: http://repository.up.ac.za/handle/2263/26367. Retrieved on 17/05/2017

Ofori, D. F., \& Hinson, R. E. (2014). Corporate social responsibility (CSR) perspectives of leading firms in Ghana. Corporate Governance: The International Journal of Business in Society, 7(2), 178-193. https://doi.org/10.1108/14720700710739813

Purushothaman, M., Tower, G., Hancock, P., \& Taplin, R. (2000). Determinants of Corporate Social Reporting Practices of Listed Singapore companies, Pacific Accounting Review, 12(2), 101-133.

PwC (2014). Sustainability Goes Mainstream: Insights Into Investors Views. [Online] Available:

http://www.pwc.com/us/en/pwc-investor-resource-institute/publications/assets/pwc-sustainabi lity-goes-mainstream-investor-views.pdf

Reynolds, S. J., Schultz, F. C., \& Hekman, D. R. (2006). Stakeholder Theory and Managerial Decision-Making: Constraints and Implications of Balancing Stakeholder Interests. Journal of Business Ethics, 64(3), 285-301. https://doi.org/10.1007/s10551-005-5493-2

Roberts, R. W. (1992). Determinants of Corporate Social Responsibility Disclosure: An Application of Stakeholder Theory. Accounting, Organizations and Society, 17(6), 595-612. https://doi.org/10.1016/0361-3682(92)90015-K

Rouf, M. A. (2011). The Corporate Social Responsibility Disclosure: A Study of Listed Companies in Bangladesh. Business and Economics Research Journal, 2(3), 19-32.

Ruf, B. M., Muralidhar, K., Brown, R. M., Janney J. J., \& Paul K. (2001). An Empirical Investigation of the Relationship Between Change in Corporate Social Performance and Financial Performance: A Stakeholder Theory Perspective. Journal of Business Ethics, 32(2), 143-156. https://doi.org/10.1023/A:1010786912118 
Salama, A., Anderson, K. P., \& Toms, S. (2011). Does community and environmental responsibility affect firm risk: Evidence from UK panel data 1994-2006. Business Ethics: A European Review, 20, 192-204. https://doi.org/10.1111/j.1467-8608.2011.01617.x

Saleh, M., Zulkifli, N., \& Muhamad, R. (2011). Looking for Evidence of the Relationship Between Corporate Social Responsibility and Corporate Financial Performance in an Emerging Market. Asia-Pacific Journal of Business Administration, 3(2), 165-190. https://doi.org/10.1108/17574321111169849

Simpson W. G. \& Kohers T. (2002). The Link between Corporate Social and Financial Performance: Evidence from the Banking Industry. Journal of Business Ethics, 35, 97-109. https://doi.org/10.1023/A:1013082525900

Smith, J. L., Adhihari, A., \& Tondkar, R. H. (2005). Exploring Differences in Social Disclosures Internationally: A Stakeholder Perspective. Journal of Accounting and Public Policy, 24(2), 123-151. https://doi.org/10.1016/j.jaccpubpol.2004.12.007

Sweeney, L., \& Coughlan, J. (April 01, 2008). Do different industries report Corporate Social Responsibility differently? An investigation through the lens of stakeholder theory. Journal of Marketing Communications, 14(2), 113-124. https://doi.org/10.1080/13527260701856657

Testa, M., \& D'Amato, A. (2017). Corporate environmental responsibility and financial performance: Does bidirectional causality work? Empirical evidence from the manufacturing industry. Social Responsibility Journal, 13(2), 221-234.

https://doi.org/10.1108/SRJ-02-2016-0031

Tsoutsoura, M. (2004). Corporate Social Responsibility and Financial Performance. University of California, Berkeley.

Ullmann A. A. (1985). Data in Search of a Theory: A Critical Examination of the Relationships Among Social Performance, Social Disclosure, and Economic Performance of U.S. Firms. Academy of Management Review, 10(3), 540-557.

https://doi.org/10.5465/amr.1985.4278989

Uwuigbe, U., \& Egbide, B. C. (2012). Corporate social responsibility disclosure in Nigeria: A study of listed financial and non-financial firms. Journal of Management and Sustainability, 2(1), 160-168. https://doi.org/10.5539/jms.v2n1p160

Waddock, S. A., \& Graves, S. B. (1997). The Corporate Social Performance-Financial Performance Link. Strategic Management Journal, 18, 303-319.

https://doi.org/10.1002/(SICI)1097-0266(199704)18:4<303::AID-SMJ869>3.0.CO;2-G

Wallace, R. S., Naser, K., \& Mora, A. (1994). The Relationship Between the Comprehensiveness of Corporate Annual Reports and Firm Characteristics in Spain. Accounting and Business Research, 25(97), 41-53.

https://doi.org/10.1080/00014788.1994.9729927

Wahba, H., \& Elsayed, K. (2015). The mediating effect of financial performance on the relationship between social responsibility and ownership structure. Future Business Journal, 
1, 1-12. https://doi.org/10.1016/j.fbj.2015.02.001

Whetten, D. A., Rodgers, Z. J., Green, C. D., \& Coles, R. S. (2014). What, Really, Constitutes a Theoretical Contribution?. Academy of Management Proceedings, 2014(1), 17067. https://doi.org/10.5465/ambpp.2014.17067abstract

\section{Appendix}

Appendix 1. Listed Firms at Nairobi Securities Exchange as at 31 December 2016

\begin{tabular}{|c|c|c|c|}
\hline S/NO. & COMPANY & ISIN CODE & TRADING \\
\hline & & & SYMBOL \\
\hline & AGRICULTURAL & & \\
\hline 1 & Eaagads Ltd & KE0000000208 & EGAD \\
\hline 2 & Kakuzi Ltd & KE0000000281 & KUKZ \\
\hline 3 & Kapchorua Tea Co. Ltd & KE4000001760 & KAPC \\
\hline 4 & The Limuru Tea Co. Ltd & KE0000000356 & LIMT \\
\hline 5 & Sasini Ltd & KE0000000430 & SASN \\
\hline \multirow[t]{2}{*}{6} & Williamson Tea Kenya Ltd & KE0000000505 & WTK \\
\hline & AUTOMOBILES \& ACCESSORIES & & \\
\hline 7 & Car \& General (K) Ltd & KE0000000109 & $\mathrm{C} \& \mathrm{G}$ \\
\hline 8 & Marshalls (E.A.) Ltd & KE0000000364 & MASH \\
\hline \multirow[t]{2}{*}{9} & Sameer Africa Ltd & KE0000000232 & FIRE \\
\hline & BANKING & & \\
\hline 10 & Barclays Bank of Kenya Ltd & KE0000000067 & $\mathrm{BBK}$ \\
\hline 11 & CFC Stanbic of Kenya Holdings Ltd & KE0000000091 & $\mathrm{CFC}$ \\
\hline 12 & Diamond Trust Bank Kenya Ltd & KE0000000158 & DTK \\
\hline 13 & Equity Group Holdings Ltd & KE0000000554 & EQTY \\
\hline 14 & Housing Finance Group Ltd & KE0000000240 & HFCK \\
\hline 15 & I\&M Holdings Ltd & KE0000000125 & $\mathrm{I} \& \mathrm{M}$ \\
\hline 16 & KCB Group Ltd Ord & KE0000000315 & $\mathrm{KCB}$ \\
\hline 17 & National Bank of Kenya Ltd & KE0000000398 & NBK \\
\hline 18 & NIC Bank Ltd & KE0000000406 & NIC \\
\hline 19 & Standard Chartered Bank Kenya Ltd & KE0000000448 & SCBK \\
\hline \multirow[t]{2}{*}{20} & The Co-operative Bank of Kenya Ltd & KE1000001568 & COOP \\
\hline & COMMERCIAL AND SERVICES & & \\
\hline 21 & Atlas African Industries Ltd & KE4000004095 & ADSS \\
\hline 22 & Express Kenya Ltd & KE0000000224 & XPRS \\
\hline 23 & Hutchings Biemer Ltd & KE0000000257 & HBER \\
\hline 24 & Kenya Airways Ltd & KE0000000307 & KQ \\
\hline 25 & Longhorn Publishers Ltd & KE2000002275 & LKL \\
\hline 26 & Nairobi Business Ventures Ltd & KE5000000090 & NBV \\
\hline 27 & Nation Media Group Ltd & KE0000000380 & NMG \\
\hline 28 & Standard Group Ltd & KE0000000455 & SGL \\
\hline 29 & TPS Eastern Africa Ltd & KE0000000539 & TPSE \\
\hline 30 & Uchumi Supermarket Ltd & KE0000000489 & UCHM \\
\hline \multirow[t]{2}{*}{31} & WPP Scangroup Ltd & KE0000000562 & SCAN \\
\hline & CONSTRUCTION \& ALLIED & & \\
\hline 32 & ARM Cement Ltd & KE0000000034 & ARM \\
\hline 33 & Bamburi Cement Ltd & KE0000000059 & BAMB \\
\hline 34 & Crown Paints Kenya Ltd & KE0000000141 & BERG \\
\hline 35 & E.A.Cables Ltd & KE0000000174 & CABL \\
\hline \multirow[t]{2}{*}{36} & E.A.Portland Cement Co. Ltd & KE0000000190 & PORT \\
\hline & ENERGY \& PETROLEUM & & \\
\hline
\end{tabular}




\begin{tabular}{|l|l|l|l|}
\hline 37 & KenGen Co. Ltd & KE0000000547 & KEGN \\
\hline 38 & KenolKobil Ltd & KE0000000323 & KENO \\
\hline 39 & Kenya Power \& Lighting Co Ltd & KE0000000349 & KPLC \\
\hline 40 & Total Kenya Ltd & KE0000000463 & TOTL \\
\hline 41 & Umeme Ltd & KE2000005815 & UMME \\
\hline & INSURANCE & & \\
\hline 42 & Britam Holdings Ltd & KE2000002192 & BRIT \\
\hline 43 & CIC Insurance Group Ltd & KE2000002317 & CIC \\
\hline 44 & Jubilee Holdings Ltd & KE0000000273 & JUB \\
\hline 45 & Kenya Re Insurance Corporation Ltd & KE0000000604 & KNRE \\
\hline 46 & Liberty Kenya Holdings Ltd & KE2000002168 & CFCI \\
\hline 47 & Pan Africa Insurance Holdings Ltd & KE0000000414 & PAFR \\
\hline & INVESTMENT & & \\
\hline 48 & Centum Investment Co Ltd & KE0000000265 & ICDC \\
\hline 49 & Home Afrika Ltd & KE2000007258 & HAFR \\
\hline 50 & Kurwitu Ventures Ltd & KE4000001216 & KURV \\
\hline 51 & Olympia Capital Holdings Ltd & KE0000000166 & OCH \\
\hline 52 & Trans-Century Ltd & KE2000002184 & TCL \\
\hline & INVESTMENT SERVICES & & \\
\hline 53 & Nairobi Securities Exchange Ltd & KE3000009674 & NSE \\
\hline & MANUFACTURING \& ALLIED & & \\
\hline 54 & A.Baumann \& Co Ltd & KE0000000018 & BAUM \\
\hline 55 & B.O.C Kenya Ltd & KE0000000042 & BOC \\
\hline 56 & British American Tobacco Kenya Ltd & KE0000000075 & BAT \\
\hline 57 & Carbacid Investments Ltd & KE0000000117 & CARB \\
\hline 58 & East African Breweries Ltd & KE0000000216 & EABL \\
\hline 59 & Eveready East Africa Ltd & KE0000000588 & EVRD \\
\hline 60 & Flame Tree Group Holdings Ltd & KE4000001323 & FTGH \\
\hline 61 & Kenya Orchards Ltd & KE0000000331 & ORCH \\
\hline 62 & Mumias Sugar Co. Ltd & KE000000000497 & KSC \\
\hline 63 & Unga Group Ltd & \\
\hline & TELECOMMUNICATION \& TECHNOLOG & \\
\hline 64 & Safaricom Ltd & SCOM \\
\hline
\end{tabular}

Appendix 2. Firms Deleted from Appendix A for Study

\begin{tabular}{|l|l|l|}
\hline S/NO. & COMPANY & Reason for Deletion \\
\hline & BANKING & \\
\hline 1 & The Co-operative Bank of Kenya Ltd & Listed 2008 \\
\hline & COMMERCIAL AND SERVICES & \\
\hline 2 & Atlas African Industries Ltd & Listed 2014 \\
\hline 3 & Hutchings Biemer Ltd & Suspended from trading 2008 \\
\hline 4 & Longhorn Publishers Ltd & Listed 2012 \\
\hline 5 & Nairobi Business Ventures Ltd & Listed 2012 \\
\hline 6 & Uchumi Supermarket Ltd & Suspended 2006, resumed trading 2011 \\
\hline & ENERGY \& PETROLEUM & \\
\hline 7 & Umeme Ltd & Listed 2012 \\
\hline 8 & INSURANCE & \\
\hline 9 & Britam Holdings Ltd & Listed 2011 \\
\hline 10 & CIC Insurance Group Ltd & Name change and reorganization in 2010 \\
\hline 11 & Kenya Re Insurance Corporation Ltd & Listed 2008 \\
\hline & Liberty Kenya Holdings Ltd & Listed 2013 \\
\hline
\end{tabular}




\begin{tabular}{|l|l|l|}
\hline 12 & Home Afrika Ltd & Listed 2012 \\
\hline 13 & Kurwitu Ventures Ltd & Listed 2014 \\
\hline 14 & Trans-Century Ltd & Listed 2013 \\
\hline & INVESTMENT SERVICES & \\
\hline 15 & Nairobi Securities Exchange Ltd & Listed 2014 \\
\hline & MANUFACTURING \& ALLIED & \\
\hline 16 & A.Baumann \& Co Ltd & Suspended in 2008 \\
\hline 17 & Flame Tree Group Holdings Ltd & Listed 2015 \\
\hline \multicolumn{2}{|c|}{ TELECOMMUNICATION \& TECHNOLOGY } \\
\hline 18 & Safaricom Ltd & Listed 2008 \\
\hline
\end{tabular}

\section{Source: Nairobi Securities Exchange:}

https://www.nse.co.ke/handbook2016-2017/companies-listings-per-date.html

\section{Copyright Disclaimer}

Copyright for this article is retained by the author(s), with first publication rights granted to the journal.

This is an open-access article distributed under the terms and conditions of the Creative Commons Attribution license (http://creativecommons.org/licenses/by/4.0/). 